\title{
Speech-language-hearing instruments to assess peripheral facial palsy: an integrative literature review
}

\author{
Mariane Maião Pereira1 \\ https://orcid.org/0000-0002-3431-3297 \\ Esther Mandelbaum Gonçalves Bianchini ${ }^{1}$ \\ https://orcid.org/0000-0002-2878-4826 \\ Mabile Francine Ferreira Silva ${ }^{2}$ \\ https://orcid.org/0000-0002-6078-4113 \\ Ruth Ramalho Ruivo Palladino' \\ https://orcid.org/0000-0001-8466-838X
}

Pontifícia Universidade Católica de São Paulo - PUC/SP, Programa de Estudos Pós-Graduados em Fonoaudiologia, São Paulo, São Paulo, Brasil.

2 Pontifícia Universidade Católica de São Paulo - PUC/SP, São Paulo, São Paulo, Brasil.

Article developed at the Pontificia Universidade Católica de São Paulo PUC/SP, São Paulo, São Paulo, Brasil.

Conflict of interests: Nonexistent

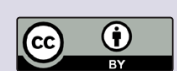

Received on: March 3, 2020

Accepted on: February 11, 2021

Corresponding address:

Mariane Maião Pereira

Rua Coelho Neto, $n^{0} 5$

CEP 11070-390 - Santos, São Paulo,

Brasil.

E-mail: marianemaiao@gmail.com

\section{ABSTRACT}

Purpose: to describe and analyze the clinical instruments that assess peripheral facial palsy through an integrative literature review.

Methods: the precepts for this type of review were followed: research question, identification, selection of studies, and critical analysis. The Virtual Health Library (VHL), Scientific Electronic Library Online (SciELO), Google Scholar, and PubMed databases were accessed to search for fully available articles published in national journals between January 2008 and July 2018. The terms used in the search were "Speech, Language and Hearing Sciences", "Evaluation", and "Facial Paralysis", in both English and Portuguese. The data obtained were organized per author, title, objective, instruments used, description of the instruments, and application procedures used in the articles.

Results: out of the total 992 articles found, only 18 met the inclusion criteria of the research. In most of them, there was only the citation of the assessment instruments or considerations about them, without fully describing the application procedures.

Conclusion: the study identified publications that indicate the use of clinical and speech-language-hearing assessment instruments. However, further detailing is necessary regarding the assessment procedures to help develop and refine the speechlanguage-hearing methodologies and techniques.

Keywords: Speech, Language and Hearing Sciences; Critical Pathways; Facial Paralysis 


\section{INTRODUCTION}

The VII cranial nerve, named the facial nerve, has peculiarities that distinguish it from other cranial nerves. One of its unique characteristics is that this nerve runs through a long path inside the bone, which helps understand the neural lesion, degeneration, and regeneration process. Thus, the facial nerve is subject to inflammatory processes caused by traumas, viral or bacterial infections, and so forth 1 .

The said lesion may lead to peripheral facial palsy (PFP), caused by reduced or interrupted axonal transport, which in turn paralyzes either totally or partially the mimic and expression of the affected hemiface. Also, changes may occur in taste, salivation, lacrimation, hyperacusis, and external auditory canal hypesthesia ${ }^{2-4}$.

The peripheral facial palsy prognosis is usually satisfactory, as 80 to $90 \%$ of the patients soon recover. As for the others, if they do not have satisfactory results within 6 months, they may have moderate to severe sequelae. When PFP has an unsatisfactory prognosis, risk factors are considered: having severe facial palsy, being older than 60 years, having Ramsay Hunt syndrome, and secondary PFP5.

The adequate PFP treatment requires a precise and in-depth clinical evaluation to investigate the impairment of the facial nerve, the etiology, degree of severity, detailed diagnosis, and clinical prognosis ${ }^{5}$. The examinations needed for the clinical investigation of the condition encompass blood tests, audiometric tests, imaging tests (such as computed tomography scan and/or magnetic resonance imaging), electrophysiological tests (such as electroneuromyography), and so on ${ }^{6}$.

The House-Brackmann scale $(\mathrm{HB})^{7}$, described in 1985, is widely used to identify the degree of impairment and clinical evolution of PFP in patients. It is divided into six degrees, namely: normal (I), slight dysfunction (II), moderate dysfunction (III), moderately severe dysfunction (IV), severe dysfunction (V), and total paralysis $(\mathrm{VI})$. This is evaluated by the physician, though other health professionals, including the speech-language-hearing (SLH) therapist, may also use the scale.

The initial aspects to be considered in SLH evaluation are the previous complaint history, time of PFP onset, gradual or sudden loss of the face movements face, spontaneous improvement, and treatment history ${ }^{1,5,6}$.
The SLH clinical evaluation is essential to diagnose orofacial myofunctional aspects, helping define the changes that take place in PFP, such as mobility, muscle tone, proprioception, subtle speech, chewing, and swallowing changes, and possible sequelae of PFP'.

There are various evaluation approaches, and the instruments chosen to be used in the SLH clinic determine the success of the therapy. A detailed SLH evaluation considering the function of each facial mimic musculature provides a more detailed view that enables the severity of the changes to be established and compared with the evolution throughout the treatment ${ }^{1}$.

Knowing the assessment instruments available to the SLH therapist and using them properly can help define the planning and the clinical prognosis of PFP. For an in-depth evaluation, the instruments must be standardized, precise, and effective in their approach and extensive detailing, contributing to the therapeutic rationale.

Achieving satisfactory and effective results in PFP treatment means the person's recovering their facial expression and mimic functions. Moreover, it makes the person recover their identity with facial expressions, a fundamental element in human communication ${ }^{8-11}$.

Thus, this research aimed to describe and analyze the clinical assessment instruments of PFP through an integrative literature review.

\section{METHODS}

This study was designed as an integrative literature review because it summarizes the state of the knowledge of a given topic, besides revealing gaps in it that need to be filled with new studies ${ }^{12}$.

This study was methodologically designed based on the research question: "What assessment instruments can be used by SLH therapists when attending people presented with PFP?".

The articles were surveyed in national - Virtual Health Library (VHL), Google Scholar, and Scientific Electronic Library Online (SciELO) - and international databases - PubMed. These were chosen for being the most researched databases, containing the main scientific health science journals, and being open access to the public or via universities in Brazil.

The terms used to search the publications in these databases were the following: "facial paralysis" combined with "evaluation" and "Speech, Language and Hearing Sciences", in both English and Portuguese. The search keys used were: "facial 
paralysis" AND "evaluation", "facial paralysis" AND "Speech, Language and Hearing Sciences", "facial paralysis" AND "evaluation" AND "Speech, Language and Hearing Sciences".

The following inclusion criteria were established to select the studies for this review: Fully available scientific articles approaching SLH evaluation of people with PFP, published between January 2008 and July 2018. The exclusion criteria encompassed repeated publications and studies that did not describe the PFP assessment instruments.

The studies were selected through stages, namely: 1) Researching the publications in each predefined database; 2) Systematizing all the studies identified in Microsoft Office Excel 2016 for the researchers' control; 3) Preselecting the studies according to the preestablished inclusion criteria, excluding the repeated articles; 4) Selecting the articles that answered the research question (i.e., that approached the SLH assessment instruments for PFP) by reading their title and abstract, when available; 5) Checking, by a second assessor, the sample of publications selected in each database; 6) Fully reading the selected studies and extracting their data (authors, title, objectives, and PFP assessment instruments); 7) Defining the articles to be included in the review based on the description of the assessment instruments used.

After the survey, the results were summarized into two tables with the authors, title, objective, and instrument used for PFP assessment. The description was subdivided into SLH assessment instruments and self-reported and quality-of-life assessment instruments. Then, the instruments found were described.

The selected articles were analyzed based on the data of the abovementioned summary. The analysis made it possible to know the evaluation procedures and the selection of assessment instruments, systematizing them to better understand the scientific productions on the investigated topic.

\section{LITERATURE REVIEW}

A total of 992 publications were identified in the database search, of which 18 articles were included in the review. The organizational chart with the detailed study identification, selection, and inclusion process is shown in Figure 1.

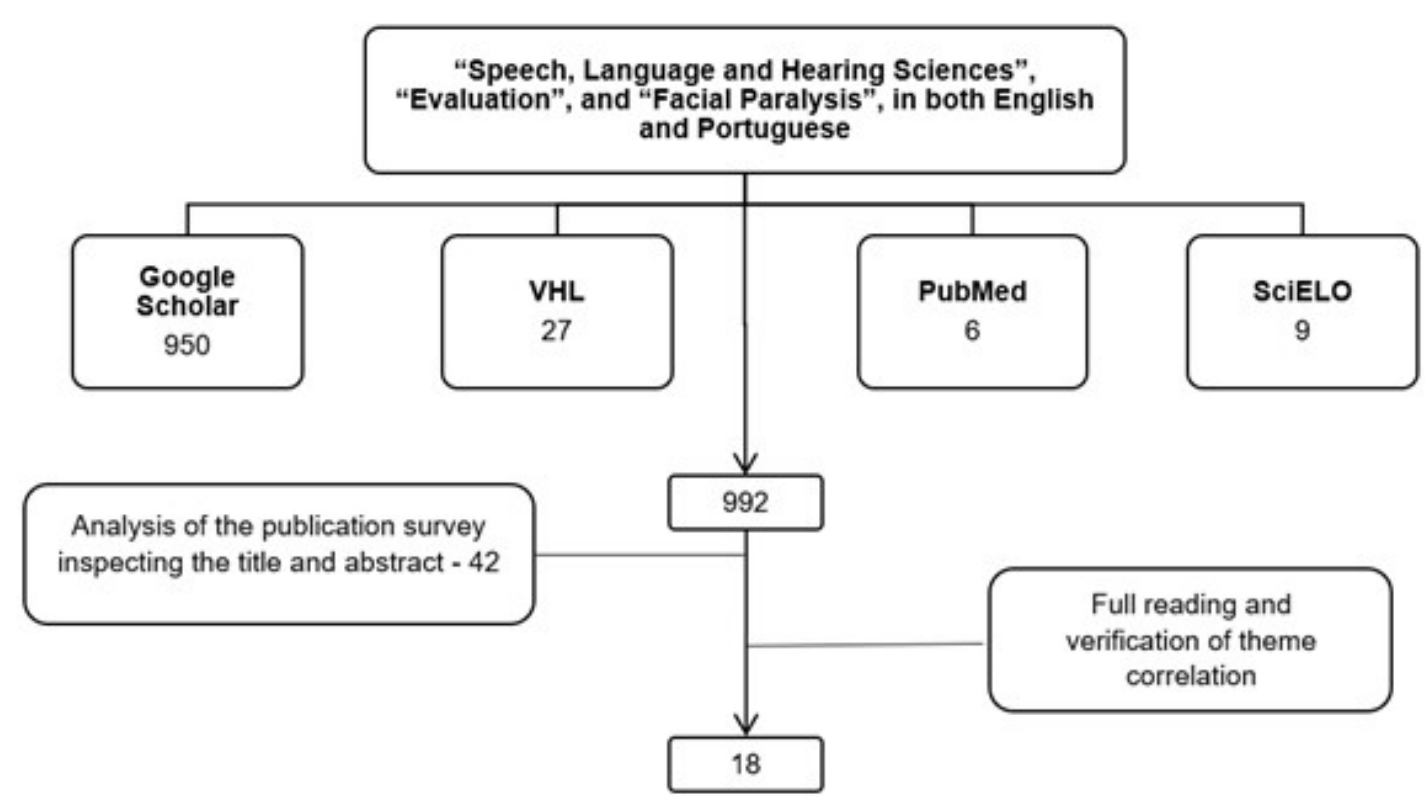

Figure 1. Presentation of the survey conducted in the databases 
The findings were organized as charts in the chronological order of publication in the journals and subdivided into SLH assessment instruments (Chart 1) and self-reported and quality-of-life assessment instruments

(Chart 2).

Chart 1. Result of the literature review on speech-language-hearing assessment instruments

\begin{tabular}{|c|c|c|c|}
\hline Authors & Title & Objective & Assessment instruments \\
\hline $\begin{array}{l}\text { FREITAS et al. } \\
(2008)^{13}\end{array}$ & $\begin{array}{l}\text { Degree of perception and } \\
\text { discomfort regarding the facial } \\
\text { condition in subjects with } \\
\text { peripheral facial paralysis in } \\
\text { sequelae stage }\end{array}$ & \begin{tabular}{|} 
To correlate the patient's self- \\
assessment of the facial condition, \\
its degree of discomfort regarding \\
the sequelae, and the impairment in \\
daily attitudes, with data found in the \\
speech-language-hearing assessment.
\end{tabular} & - Facial Grading System ${ }^{14}$ \\
\hline $\begin{array}{l}\text { ALBUQUERQUE } \\
\text { et al. }(2009)^{15}\end{array}$ & $\begin{array}{c}\text { Möbius Sequence: anamnesis } \\
\text { and evaluation protocol: a case } \\
\text { report }\end{array}$ & $\begin{array}{l}\text { To disseminate the protocol used at } \\
\text { the institution where the research } \\
\text { was conducted with patients with } \\
\text { Möbius syndrome, and report a case } \\
\text { attended at the service for the sake of } \\
\text { exemplification. }\end{array}$ & $\begin{array}{l}\text { - Structural and functional speech- } \\
\text { language-hearing evaluation of phono- } \\
\text { articulatory organs in children with } \\
\text { congenital facial palsy }{ }^{15}\end{array}$ \\
\hline $\begin{array}{l}\text { TESSITORE } \\
\text { et al. }(2009)^{16}\end{array}$ & $\begin{array}{l}\text { Peripheral facial paralysis: } \\
\text { evaluation of an orofacial } \\
\text { rehabilitation protocol }\end{array}$ & $\begin{array}{l}\text { To assess the proposed protocol for } \\
\text { orofacial neuromuscular rehabilitation } \\
\text { in cases of peripheral facial palsy. }\end{array}$ & $\begin{array}{l}\text { - House-Brackmann Scale }{ }^{7} \\
\text { - Lip Commissure Angle Assessment }{ }^{17} \\
\text { - Photographic documentation }\end{array}$ \\
\hline $\begin{array}{l}\text { BERNARDES } \\
\text { et al. }(2010)^{18}\end{array}$ & $\begin{array}{c}\text { Surface electromyography in } \\
\text { peripheral facial paralysis patients }\end{array}$ & $\begin{array}{l}\text { To study the electromyographic activity } \\
\text { of the frontalis, orbicularis oculi, } \\
\text { zygomaticus major, and orbicularis } \\
\text { oris muscles in normal people and } \\
\text { patients with facial palsy, as well as the } \\
\text { symmetry rate between the two sides } \\
\text { of the face. }\end{array}$ & $\begin{array}{l}\text { - House-Brackmann Scale } \\
\text { - Surface electromyography }\end{array}$ \\
\hline $\begin{array}{l}\text { TESSITORE } \\
\text { et al. }(2010)^{19}\end{array}$ & $\begin{array}{l}\text { Angular measurement for } \\
\text { determining muscle tonus in } \\
\text { facial paralysis }\end{array}$ & $\begin{array}{l}\text { To propose the lip commissure angle } \\
\text { and assess its reliability as an objective } \\
\text { resource to assess facial muscle tone } \\
\text { changes in the evolution of facial palsy. }\end{array}$ & $\begin{array}{c}\text { - Photographic documentation } \\
\text { - Video documentation } \\
\text { - House-Brackmann Scale } \\
\text { - Lip Commissure Angle Assessment }{ }^{7}\end{array}$ \\
\hline $\begin{array}{l}\text { BIANCHINI et } \\
\text { al. }(2010)^{20}\end{array}$ & $\begin{array}{l}\text { Interdisciplinary approach for } \\
\text { comminuted condyle fracture } \\
\text { of by firearms - myofunctional } \\
\text { focus }\end{array}$ & $\begin{array}{l}\text { To present the procedures and } \\
\text { results obtained in the nonsurgical } \\
\text { treatment associated with orofacial } \\
\text { myofunctional therapy, in a clinical } \\
\text { case of comminuted condyle fracture } \\
\text { causing traumatic facial palsy due to } \\
\text { firearm projectile. }\end{array}$ & $\begin{array}{l}\text { - Assessment protocol20 } \\
\text { - Photographic documentation }\end{array}$ \\
\hline $\begin{array}{l}\text { ROSA et al. } \\
(2010)^{21}\end{array}$ & \begin{tabular}{|c|} 
Comparison between \\
myofunctional therapy and \\
myofunctional therapy associated \\
with acupuncture on treatment for \\
peripheral facial paralysis \\
\end{tabular} & $\begin{array}{l}\text { To compare the effectiveness of } \\
\text { speech therapy and acupuncture } \\
\text { associated with speech therapy in } \\
\text { patients with PFP. }\end{array}$ & $\begin{array}{c}\text { - Digital caliper } \\
\text { - Assessment protocol }\end{array}$ \\
\hline $\begin{array}{l}\text { SASSI et al. } \\
(2011 \mathrm{a})^{22}\end{array}$ & $\begin{array}{c}\text { Mandibular range of motion in } \\
\text { patients with idiopathic peripheral } \\
\text { facial palsy }\end{array}$ & $\begin{array}{l}\text { To correlate electromyographical data } \\
\text { of the muscles that lift the angle of the } \\
\text { mouth with the facial inability rate in } \\
\text { patients with long-lasting facial palsy. }\end{array}$ & $\begin{array}{l}\text { - Assessment protocol23 } \\
\text { - Surface electromyography } \\
\text { - Photographic documentation }\end{array}$ \\
\hline $\begin{array}{l}\text { SASSI et al. } \\
(2011 \mathrm{~b})^{24}\end{array}$ & $\begin{array}{l}\text { Correlation between electromyo- } \\
\text { graphic data and facial disability } \\
\text { index in patients with long-term } \\
\text { facial paralysis: implications for } \\
\text { treatment outcomes }\end{array}$ & $\begin{array}{l}\text { To correlate electromyographical data } \\
\text { of the muscles that lift the angle of the } \\
\text { mouth with the facial inability rate in } \\
\text { patients with long-lasting facial palsy. }\end{array}$ & $\begin{array}{l}\text { - Assessment protocol23 } \\
\text { - Surface electromyography }\end{array}$ \\
\hline
\end{tabular}




\begin{tabular}{|c|c|c|c|}
\hline Authors & Title & Objective & Assessment instruments \\
\hline $\begin{array}{l}\text { SALVADOR et } \\
\text { al. }(2011)^{25}\end{array}$ & $\begin{array}{c}\text { Measurement of evolution } \\
\text { therapy using a digital caliper in } \\
\text { palsy Bell }\end{array}$ & $\begin{array}{l}\text { To assess the use of the digital caliper } \\
\text { to measure facial mimic movements } \\
\text { at different moments of the speech- } \\
\text { language-hearing treatment. }\end{array}$ & - Digital caliper \\
\hline $\begin{array}{l}\text { JESUS \& } \\
\text { BERNARDES } \\
(2012)^{26}\end{array}$ & $\begin{array}{c}\text { Functional characterization of } \\
\text { facial mimicry in facial paralysis } \\
\text { of face trauma: a clinical case } \\
\text { report }\end{array}$ & $\begin{array}{l}\text { To describe, based on the speech- } \\
\text { language-hearing assessment, the } \\
\text { characteristics of the facial mimic in } \\
\text { facial palsy caused by facial trauma. }\end{array}$ & $\begin{array}{l}\text { - House-Brackmann Scale } \\
\text { - Chevalier Scale }\end{array}$ \\
\hline $\begin{array}{l}\text { MIRANDA et al. } \\
\qquad(2015)^{28}\end{array}$ & $\begin{array}{l}\text { Effectiveness of speech therapy } \\
\text { in patients with facial paralysis } \\
\text { after parotidectomy }\end{array}$ & $\begin{array}{l}\text { To verify the effectiveness of speech } \\
\text { therapy in patients with facial palsy } \\
\text { due to manipulation of the VII cranial } \\
\text { nerve during surgery to treat parotid } \\
\text { gland neoplasm, as well as identify } \\
\text { and promote speech-language-hearing } \\
\text { interventions of sucking, chewing, and } \\
\text { swallowing changes. }\end{array}$ & $\begin{array}{l}\text { - Assessment protocol }{ }^{1} \\
\text { - Digital caliper }\end{array}$ \\
\hline $\begin{array}{l}\text { FONSECA et al. } \\
\qquad(2015)^{29}\end{array}$ & $\begin{array}{l}\text { Scales of the degree of facial } \\
\text { paralysis: analysis of the } \\
\text { agreement }\end{array}$ & $\begin{array}{l}\text { To analyze the inter- and intra-assessor } \\
\text { agreement regarding the scales of } \\
\text { the degree of facial palsy and the } \\
\text { assessors' opinion about their use. }\end{array}$ & $\begin{array}{l}\text { - House-Brackmann Scale } \\
\text { - Chevalier Scale }{ }^{27}\end{array}$ \\
\hline $\begin{array}{l}\text { ROMÃO et al. } \\
(2015)^{30}\end{array}$ & $\begin{array}{l}\text { Early speech therapy intervention } \\
\text { in a patient with facial paralysis } \\
\text { after otomastoiditis }\end{array}$ & $\begin{array}{c}\text { To rehabilitate a patient presented } \\
\text { with facial palsy after otomastoiditis } \\
\text { with early speech-language-hearing } \\
\text { intervention, and describe the } \\
\text { application of a differentiated therapy } \\
\text { intervention approach. }\end{array}$ & $\begin{array}{c}\text { - Photographic documentation } \\
\text { - Digital caliper }{ }^{31}\end{array}$ \\
\hline $\begin{array}{l}\text { SILVA et al. } \\
(2016)^{10}\end{array}$ & $\begin{array}{c}\text { Multidisciplinary care of } \\
\text { peripheral facial palsy: a clinical } \\
\text { case study }\end{array}$ & $\begin{array}{l}\text { To report a peripheral facial palsy } \\
\text { case and the effectiveness of } \\
\text { multidisciplinary care }\end{array}$ & $\begin{array}{l}\text { - House-Brackmann Scale } \\
\text { - Facial Grading System }{ }^{14}\end{array}$ \\
\hline $\begin{array}{l}\text { WENCESLAU } \\
\text { et al. }(2016)^{32}\end{array}$ & $\begin{array}{l}\text { Peripheral facial palsy: muscle } \\
\text { activity in different onset times }\end{array}$ & $\begin{array}{l}\text { To assess with EMG the activity of } \\
\text { the risorius and zygomaticus muscles } \\
\text { when voluntarily smiling, comparing } \\
\text { the data between two groups of people } \\
\text { with different time of peripheral facial } \\
\text { palsy onset. }\end{array}$ & $\begin{array}{l}\text { - Assessment protocol }{ }^{23} \\
\text { - Surface electromyography }\end{array}$ \\
\hline
\end{tabular}

Chart 2. Result of the literature review of the self-reported and quality-of-life assessment instruments

\begin{tabular}{|c|c|c|c|}
\hline Authors & Title & Objective & Assessment instruments \\
\hline $\begin{array}{c}\text { SILVA et al. } \\
(2011)^{34}\end{array}$ & $\begin{array}{c}\text { Psychological contents and } \\
\text { social effects associated to } \\
\text { peripheral facial paralysis: a } \\
\text { speech-language approach }\end{array}$ & $\begin{array}{c}\text { To investigate the psychological } \\
\text { contents and the effects associated } \\
\text { with PFP in adult subjects, with } \\
\text { comparative analysis in three groups } \\
\text { of people with PFP: in the flaccid, } \\
\text { recovery, and sequela phases. }\end{array}$ & $\begin{array}{c}\text { - Photographic documentation } \\
\text { - Chevalier Scale }\end{array}$ \\
\hline $\begin{array}{c}\text { SANTOS \& } \\
\text { GUEDES (2011) }\end{array}$ & $\begin{array}{c}\text { Study on the quality of life in } \\
\text { subjects with acquired chronic } \\
\text { peripheral facial palsy }\end{array}$ & $\begin{array}{c}\text { To analyze the quality of life in people } \\
\text { with acquired chronic PFP. }\end{array}$ & $\begin{array}{c}\text { - degree of perceived discomfort due } \\
\text { to the facial condition in people with } \\
\text { peripheral facial palsy in the phase of } \\
\text { sequelae }{ }^{36}\end{array}$ \\
\hline
\end{tabular}




\section{Description of the Instruments Found in the Research}

Facial Grading System ${ }^{14}$ : The Facial Grading System aims to evaluate the face at rest and making mimic movements: raising the forehead, smiling, pouting, lifting the nose, and closing the eyes. It also quantifies the contractures and synkinesis in cases of sequelae. An overall assessment grade is obtained, which corresponds to the movement grade minus the at-rest and synkinesis grade. This instrument was used in other studies as well ${ }^{10,13}$.

House-Brackmann Scale ${ }^{7}$ : The HB scale evaluates the face at rest and in movement, such as raising the eyebrows, closing the eyes, smiling, and pouting. The classification comprises six degrees, namely: I - Normal; II - Slight dysfunction; III -Moderate dysfunction; IV - Moderately severe dysfunction; V Severe dysfunction; $\mathrm{VI}$ - Total paralysis.

In one of the studies ${ }^{16}$, the HB scale was used to measure the degree of PFP in video recordings, whereas the other article did not give details about this measure.

Another study suggested using the anthropometric measurement of the face to assess and compare PFP. The instrument was meant to assess the face at rest symmetry and tone - and in movement - forehead, eyes, and mouth ${ }^{35}$.

A third study ${ }^{29}$ commented that in this scale the assessment is conducted separately, considering the three different sections: forehead, eyes, and mouth. Also, the HB scale allows the assessor to analyze the face both at rest and in movement.

Other articles were found ${ }^{10,18,19,22,26,34}$ in which the HB scale was used by a neurologist or SLH therapist.

Chevalier Scale ${ }^{27}$ : The Chevalier Scale was used by assessors who asked the patient to respond to verbal and visual commands for movement assessment, considering each facial mimic muscle individually and classifying them as normal, partially changed, or totally changed ${ }^{26}$.

The patient should respond to commands such as "look scared", "look angry", "look like ugly smell", "shave the mustache", "close your eyes gently", "close your eyes tightly", "smile with mouth closed", "smile with open mouth", "contract the cheeks", "show your lower teeth", "lift your chin", "contract the neck muscles", and "pout" 26 .

This process took place in other studies ${ }^{29,34}$ with the same scale. However, in the assessment of facial musculature mobility, the patients were asked to make each movement five times to establish more precisely one of the five degrees $(0-$ not visible contraction either with the naked eye or overhead light, to 4 - the movement is broad, synchronous, and symmetrical with the healthy side).

Photographic Documentation: Used to assess facial tone at absolute rest to record the lip commissure angle assessment $(\text { LCA })^{16}$.

In another study ${ }^{34}$, the functional condition assessment was photographed to record and confirm it. This resource can be used to assess the face at rest $^{26}$.

The photographic documentation can be used to record the face of the patient while making expressions such as rest, faint smile, open smile, eyes closed, raised forehead, pout, scared face, and ugly-smell face, to identify changes in facial mobility in upper, lower, or midface $^{24,32}$.

Video Documentation: Two articles used this instrument, though neither of them had bibliographical references of the procedure. The video documentation was used to assess facial movements and grade the PFP on the HB scale ${ }^{16}$.

To this end, the patients were asked to do the following tasks twice: say their full name and count from 1 to 10 , raise their eyebrows and relax (look surprised), narrow the eyebrows (look angry), blink gently, close the eyelids gently (zoom in), close the eyelids tightly, contract the nose musculature (ugly-smell face), pout and relax, blow the cheeks, smile with the mouth closed and relax, lower the corners of the mouth and relax, and lastly smile with mouth open and relax ${ }^{15}$.

Surface Electromyography (EMG): The EMG was used to pick up the muscle activity with surface electrodes attached to the face ${ }^{18}$. This article ${ }^{18}$ did not furnish any bibliographical references of the procedure. The electrodes were placed on both sides of the face, on the frontalis, orbicularis oculi, and orbicularis oris muscles (simultaneously), and the zygomaticus major and orbicularis oculi muscles (simultaneously), whereas the ground electrode was placed under the sternocleidomastoid muscle.

The patients performed the following seven tasks with maximum effort for 8 seconds: raising the forehead, closing the eyes tightly, the activity of the lips while closing the eyes tightly, protruding the lips, the activity of the eyes while protruding the lips, retracting the lips, and activity of the eyes while retracting the lips.

Likewise, another article ${ }^{33}$ did not have any bibliographical reference of the use of EMG. The authors did 
not explain the positioning of the electrodes, although they pointed out that each participant was instructed to remain as still and relaxed as possible for 1 minute. Three independent collections were made at rest, each one lasting 30 seconds. After the rest, each participant was asked to smile voluntarily for 5 seconds and then keep the musculature relaxed for another 5 seconds; this procedure was repeated three times.

One study ${ }^{25}$ performed surface EMG assessment based on the methodology of a previous study ${ }^{30}$, assessing the muscle groups involved in smiling (risorius and zygomaticus). The electrical activity of the risorius and zygomaticus muscles was assessed in both hemifaces. Each muscle region was assessed separately while at rest and smiling voluntarily as open as possible.

Digital Caliper: The research that used this instrument did not present any bibliographical reference they followed. Hence, the description made here is of measuring made in the research.

The measurements were made in facial mimic movement, always going from a fixed point to a movable point: the caliper was first placed at the tragus (fixed point) opening to the lip commissure. Then, the fixed point was the outer corner of the eye, opening to the lip commissure. Lastly, it was placed on the inner corner of the eye opening to the ala nasi.

Another study ${ }^{32}$, on the other hand, presented a reference ${ }^{17}$ also measuring from the lip commissure to the tragus at rest, in a faint smile and open smile.

Structural and functional SLH evaluation of phono-articulatory organs in children with congenital facial palsy ${ }^{20}$ : Intended for anamnesis followed by the assessment of the child's stomatognathic system.

The investigation encompassed mobility, motor functions, tone, and posture of the phono-articulatory organs (lip, tongue, cheeks, palate, mandible, maxilla, teeth), as well as the activities of the neurovegetative functions (sucking, swallowing, chewing, and breathing). Also, the muscles responsible for facial expression were assessed individually to obtain data on those patients' actual manifestations.

Lip Commissure Angle Assessment (LCA): In the studies found ${ }^{16,19}$ the LCA was measured with a caliper, according to the bibliography ${ }^{21}$. According to the articles, the LCA is determined following the line that connects anthropometric points: from the glabella (the most prominent part between the eyebrows or between the epicanthal folds) to the gnathion (the junction of the two hemimandibles, forming a shallow fossa).

Crosswise to this line, another one was traced passing from the right cheilion to the left cheilion (the junction that forms the lip commissure). The glabella and gnathion are fixed points, while the cheilion on the paralyzed side is a movable point.

The crossing of these lines forms the LCA, which is measured with a protractor.

Assessment procedures for psychological contents and social effects associated with PFP ${ }^{34}$ : The principles of the assessment instrument used in the research aimed to investigate the psychological contents and the social effects associated with PFP in adult subjects to achieve greater effectiveness in the SLH clinical method. The face was assessed to compare the degree of severity, stage of the PFP, and psychological and social contents based on the Chevalier Scale ${ }^{27}$.

Questionnaire on the person's opinion about their face regarding the muscles at rest and in movement $^{13}$ : In one of the studies ${ }^{35}$, this closedended questionnaire was administered to the subjects concerning the presence of complaint, and degree of discomfort due to synkinesis and contractures, as well as loss in social and professional activities. The questions were asked during the assessment and were divided into the following four items for the patient's self-assessment:

1. Assessment of the face at rest (scoring from 0 horrible, to 4 - great);

2. Assessment of the face when moving the forehead, eyes, nose, and lips (scoring from 0 - horrible, to 4 - great);

3. Presence of complaint and degree of discomfort due to synkinesis and contractures $(0-$ none, to 4 - much);

4. Loss in social and professional activities and its degree (0 - none, to 4 - much).

The questions were analyzed and compared with the degree of facial palsy, according to the HB scale.

\section{Description of the Protocols Used in Research}

Orofacial Myofunctional Assessment Protocol ${ }^{23}$ : Used to observe aspects of oral-motor functions, such as response to pain, limited head movement, motor and sensitivity deficit, bite, maximum mouth amplitude, mandible lateralization, along with other functional aspects. In the article found ${ }^{33}$, this protocol was used 
for assessment before and after SLH myofunctional therapy.

PFP Anamnesis and Assessment Protocol': The research that included this protoco ${ }^{36}$ counts on the instrument ${ }^{17}$ to measure facial palsy with a digital caliper. The rest of the study was developed following the said protocol with some adaptations conducted by the author.

Facial Palsy Clinical Assessment Protocol ${ }^{37}$ : In these studies ${ }^{22,25,33}$ the instrument ${ }^{37}$ verified the aesthetic/functional symmetry of the face. The muscle groups in each hemiface were assessed in different voluntary facial expressions, scoring zero $(0)$ if there was no movement; one (1) if there was a partial or moderate movement; and two (2) if there was a complete or sharp movement.

The frontal region was assessed raising the eyebrows, moving the eyelids to close the eyes, lifting the upper lip while wrinkling the nose, slanting the upper lip to smile, moving the upper lip sideways in a cynical smile, closing the lips in protrusion, and contracting the lower lip to show the lower teeth.

Facial palsy assessment and measuring protocol with a digital caliper and evaluation of the stomatognathic functions ${ }^{24}$ : This is a set of instruments $s^{1,17,27}$ developed to measure the facial movement with a caliper. Also, the stomatognathic functions were assessed, namely: sucking, chewing, and swallowing, with the following consistencies: liquid (water), creamy (yogurt), and solid (sandwich cookie). The patients were not given any instructions for the functional observation, except being asked to consume the food in their usual manner.

Oral-motor function assessment protocol ${ }^{32}$ : This protocol is an adaptation of previous studies ${ }^{37,38}$ to enable more detailed observations of the phono-articulatory organs and the functions of the stomatognathic system $^{32}$.

Most of the articles approached here do not allow the assessment instruments to be visualized; many of them only cite the instrument and do not describe how it was used. Among the ones that do, the most present instrument is the photographic documentation, used in five articles, and the HB Scale ${ }^{7}$, described in four articles. In other ones, the assessment instruments were only cited as inclusion criteria of the research according to the degree of paralysis.

Despite being the oldest assessment instrument cited, the HB Scale is still the most renowned and used to assess the absence or presence of facial movements and asymmetry and to verify eye gap at rest.

However, in SLH therapy it is also necessary to assess the detailed facial mimic movements, as well as their functions. The survey found few instruments for such assessment, including the Facial Grading System $^{14}$, Chevalier Scale ${ }^{27}$, and the structural and functional SLH evaluation of phono-articulatory organs in children with congenital facial palsy ${ }^{20}$.

The instruments found were mostly mentioned and described, although they were not fully presented - i.e., they are used at the institutions where the studies were carried out. Of the abovementioned ones, the validation of the Facial Grading System ${ }^{14}$, Chevalier Scale ${ }^{27}$, and HB Scale was cited ${ }^{7}$.

Some of the studies analyzed used assessment instruments to obtain numerical and comparative data. That was the case of the caliper ${ }^{17,32}$, EMG ${ }^{18,25,30,33}$, photographic record, and video record ${ }^{16,34}$, whose importance is pointed out both to assess and follow up the evolution of the case.

As years go by, the instruments become even more specific, which means they assess precise aspects of PFP. The literature review showed an increased number of studies in 2011, although it decreased in the following years.

Another problem found in the research was the difference between instrument and protocol. The instrument is characterized as a tool or material the professional uses to plan the protocol - hence, the protocols are a set of instruments ${ }^{38}$. The protocols found in the researched articles were the Myofunctional Assessment Protocol ${ }^{23}$, PFP Anamnesis and Assessment Protocol ${ }^{1}$, and Facial Palsy Clinical Assessment Protocol ${ }^{37}$. Each of these was cited in only one article.

Only two articles were found on the quality of life, referring to the subject's self-assessment of their problem - Assessment procedures for psychological contents and social effects associated to PFP ${ }^{34}$ and Questionnaire on the person's opinion about their face regarding the muscles at rest and in movement ${ }^{13}$. Both conclude that regardless of the degree of PFP, the social consequences have an impact on the subject's life and can interfere with clinical recovery.

The importance of instruments that show the patient's view of their problem must be highlighted, as they point out their anguish, anxiety, and frustration regarding the possible changes taking place in their life, due to PFP ${ }^{10,11}$. 


\section{CONCLUSION}

This literature review identified relevant publications indicating the use of SLH and clinical instruments to assess PFP. Altogether, the data provide a compilation of procedures with different types/objectives/contents, which can be complementarily used in clinical practice.

However, the papers need to provide further details of the assessment procedures to help develop and refine SLH methodologies and techniques to be used in cases of PFP.

These data are expected to contribute to further research on SLH assessment of PFP. It is suggested that protocols be developed, as well as result markers need to be continuously studied and validated to improve the clinical and therapeutic approaches used in SLH practices.

\section{REFERENCES}

1. Lazarini PR, Fouquet ML. Paralisia facial: avaliação, tratamento e reabilitação. São Paulo: Lovise; 2006.

2. Adams RD. Neurologia. McGraw-Hil. Rio de Janeiro; 1998.

3. Valença MM, De Andrade Valença LPA, Lima MCM. Paralisia facial periférica idiopática de Bell: a propósito de 180 pacientes. Arq Neuropsiquiatr. 2001;59(3 B):733-9.

4. Vasconcelos BEC, De Oliveira e Silva ED, Dantas WRM, Barros ES, Monteiro GQM. Paralisia facial periférica traumática. Rev Cir Traumat Buco-MaxiloFacial. 2001;1(2):13-20.

5. Finsterer J. Management of peripheral facial nerve palsy. J Eur Arch Otorhinolaryngol. 2008;265(7):743-52.

6. Dib GC, Kosugi EM, Antunes ML. Paralisia facial periférica. Rev Bras Med. 2004;61(3):110-7.

7. House JW, Brackmann DE. Facial nerve grading system. Otolaryngol Head Neck Surg. 1985;93(2):146-7.

8. Chu EA, Farrag TY, Ishii LE, Byrne PJ. Threshold of visual perception of facial asymmetry in a facial paralysis model. Arch Facial Plast Surg. 2011;13(1):14-9.

9. Ishii LE, Godoy A, Encarnacion CO, Byrne PJ, Boahene KDO, Ishii M. Not just another face in the crowd: society's perceptions of facial paralysis. Laryngoscope. 2012;122(3):533-8.
10. Silva MFF, Cunha MC. Theoretical considerations about the physical, psychological and social impact on peripheral facial paralysis. Distúrb. Comun. 2016;28(1):175-80.

11. Silva MFF, Peres SV, Tessitore A, Paschoal JR, Cunha MC. Application of the psychosocial scale of facial appearance in the evaluation of peripheral facial palsy: a pilot study. Audiol., Commun. Res. 2016;21:e1618.

12. Mendes KDS, Silveira RC de CP, Galvão CM. Revisão integrativa: método de pesquisa para a incorporação de evidências na saúde e na enfermagem. Texto Context - Enferm. 2008;17(4):758-64.

13. Freitas KCS de, Gómez MVG. Grau de percepção e incômodo quanto à condição facial em indivíduos com paralisia facial periférica na fase de sequelas. Rev. Soc. Bras. Fonoaudiol. 2008;13(2):113-8.

14. Ross BG, Fradet G, Nedzelski J. Development of a sensitive clinical facial grading system. Otolaryngol Head Neck Surg. 1996;114(3):380-6.

15. Albuquerque TCAL, Barreto RRDS, Costa TCCM, Guedes ZCF. Sequência de Möbius: protocolo de anamnese e avaliação - relato de caso. Rev. Soc. Bras. Fonoaudiol. 2009;14(1):115-22.

16. Tessitore A, Paschoal JR, Pfeilsticker LN. Avaliação de um protocolo da reabilitação orofacial na paralisia facial periférica. Rev. CEFAC. 2009;11(3):432-40.

17. Cattoni DM, Fernandes FD, Di Francesco RC, Latorre M. Características do sistema estomatognático de crianças respiradoras orais: enfoque antroposcópico. Pró-Fono R. Atual. Cientif. 2007;14(4):347-51.

18. Bernardes D, Gomez M, Bento R. Eletromiografia de superficie em pacientes portadores de paralisia facial periférica. Rev. CEFAC. 2010;12(1):91-6.

19. Tessitore A, Magna LA, Paschoal JR. Medida angular para aferição do tônus muscular na paralisia facial. Pró-Fono R. Atual. Científ. 2010;22(2):119-24.

20. Bianchini EMG, Moraes RB, Nazario D, Luz JG de C. Terapêutica interdisciplinar para fratura cominutiva de côndilo por projétil de arma de fogo: enfoque miofuncional. Rev. CEFAC. 2010;12(5):881-8.

21. Rosa MC, Moreira AFM, Araújo LB, Moreira Junior LC, Motta AR. Comparação dos resultados da fonoterapia e fonoterapia associada à acupuntura. Rev. CEFAC. 2010;12(4):579-88. 
22. Sassi FC, Davison ML, Poluca MC, Ferreira BR, Furquim ACR. Mandibular range of motion in patients with idiopathic peripheral facial palsy. Braz. J Otorhinolaryngol. 2011;77(2):237-44.

23. Salles AG, Toledo PN, Ferreira M. Botulinum toxin injection in long-standing facial paralysis patients: improvement of facial symmetry observed up to 6 months. Aesthetic Plast. Surg. 2009;33(4):582-90.

24. Sassi F, Toledo P, Mangilli L, Alonso N, Andrade CRF. Correlação entre eletromiografia e índice de inabilidade facial em pacientes com paralisia facial de longa duração: implicações para o resultado de tratamentos. Rev. Bras. Cir. Plást. 2011;26(4):596-601.

25. Salvador CHM, Tessitore A, Pfeilsticker LN, Paschoal JR, Nemr K. Mensuração da evolução terapêutica com paquímetro digital na paralisia facial periférica de Bell. Rev. CEFAC. 2011;15(3):592-8.

26. Jesus LB de, Bernardes DFF. Caracterização funcional da mímica facial na paralisia facial em trauma de face: relato de caso clínico. Rev. CEFAC. 2012;14(5):971-6.

27. Lacôte M, Chevalier AM, Miranda A, Bleton J, Stevenin P. Avaliação da função motora da face nas lesões periféricas e centrais. In: Lacôte $M$, Chevalier AM, Miranda A, Bleton JP, Stevenin P, editors. Avaliação clínica da função muscular. Manole. São Paulo; 1987. p. 13-35.

28. Miranda VHM, Scarpel RD, Torres ACM, Agra IMG. Effectiveness of speech therapy in patients with facial paralysis after parotidectomy. Rev. CEFAC. 2015;13(3):984-95.

29. Fonseca KMO, Mourão AM, Motta AR, Vicente LCC. Escalas de grau da paralisia facial: análise de concordância. Braz. J. Otorhinolaryngol. 2015;81(3):288-93.

30. Romão AM, Cabral C, Magni C. Early speech therapy intervention in a patient with facial paralysis after otomastoiditis. Rev. CEFAC. 2015;17(3):996-1003.

31. Quintal M, Tessitore A, Paschoal JR, Pfeilsticker LN. Quantificação da paralisia facial com paquímetro digital. Rev. CEFAC. 2004;6(2):170-6.

32. Wenceslau LGC, Sassi FC, Magnani DM, Andrade CRF. Peripheral facial palsy: muscle activity in different onset times. CoDAS. 2016;28(1):3-9.

33. Sassi FC, Toledo PN, Mangilli LD, Andrade CRF. Electromyography and facial paralysis. In: Steele $\mathrm{C}$, editor. Applications of EMG in clinical and sports medicine. InTech; 2012. p. 357-9.
34. Silva MFF, Cunha MC, Lazarini PR, Fouquet ML. Conteúdos psíquicos e efeitos sociais associados à paralisia facial periférica: abordagem fonoaudiológica. Int. Arch. Otorhinolaryngol. 2011;15(4):450-60.

35. Santos RMM, Guedes ZCF. Estudo da qualidade de vida em indivíduos com paralisia facial periférica crônica adquirida. Rev. CEFAC. 2012;14(4):626-34.

36. Marchesan I. Alterações de fala de origem musculoesquelética. In: Ferreira LP, Befi-Lopes D, editors. Tratado de Fonoaudiologia. São Paulo: Roca; 2004. p. 292-303.

37. Bigenzahn W. Disfunções orofaciais na infância. 2nd ed. Sâo Paulo: Santos; 2008.

38. Fenker EA, Diehl CA, Alves TW. Desenvolvimento e avaliação de instrumento de pesquisa sobre risco e custo ambiental. Revista Contabilidade do Mestrado em Cências Contábeis da UERJ. 2011;16(2):30-49. 